\title{
Electrochemical Study of Tantalum in Fluoride and Oxofluoride Melts
}

\author{
Polyakova, L.; Polyakov, E.; Matthiesen, F.; Christensen, Erik; Bjerrum, Niels
}

Published in:

Journal of The Electrochemical Society

Link to article, DOI:

$10.1149 / 1.2059269$

Publication date:

1994

Document Version

Publisher's PDF, also known as Version of record

Link back to DTU Orbit

Citation (APA):

Polyakova, L., Polyakov, E., Matthiesen, F., Christensen, E., \& Bjerrum, N. (1994). Electrochemical Study of Tantalum in Fluoride and Oxofluoride Melts. Journal of The Electrochemical Society, 141(11), 2982-2988. https://doi.org/10.1149/1.2059269

\section{General rights}

Copyright and moral rights for the publications made accessible in the public portal are retained by the authors and/or other copyright owners and it is a condition of accessing publications that users recognise and abide by the legal requirements associated with these rights.

- Users may download and print one copy of any publication from the public portal for the purpose of private study or research.

- You may not further distribute the material or use it for any profit-making activity or commercial gain

- You may freely distribute the URL identifying the publication in the public portal 


\title{
Electrochemical Study of Tantalum in Fluoride and Oxofluoride Melts
}

\author{
L. P. Polyakova and E. G. Polyakov \\ Institute of Chemistry, KSC RAS, Apatity 184200, Russia
}

\begin{abstract}
F. Matthiesen, E. Christensen, and N. J. Bjerrum*
Materials Science Group, Chemistry Department A, The Technical University of Denmark, DK-2800 Lyngby, Denmark
\end{abstract}

\section{ABSTRACT}

The electrochemical behavior of tantalum in the form of $\mathrm{K}_{2} \mathrm{TaF}_{7}$ in an $\mathrm{LiF}-\mathrm{NaF}-\mathrm{KF}$ eutectic melt has been studied by linear voltammetry in the temperature range of 560 to $815^{\circ} \mathrm{C}$ with and without additions of $\mathrm{Na}_{2} \mathrm{O}$. An amperometric titration has been performed by measuring the heights of the cathodic and the anodic peaks. It was shown that at a molar ratio $\mathrm{Na}_{2} \mathrm{O} / \mathrm{K}_{2} \mathrm{TaF}_{7}=1$ the predominating complex in the melt is $\mathrm{TaOF} \mathrm{F}_{5}^{2-}$, whereas with an $\mathrm{Na}_{2} \mathrm{O} / \mathrm{K}_{2} \mathrm{TaF} \mathrm{F}_{7}$ molar ratio of 2 it is $\mathrm{TaO}_{2} \mathrm{~F}_{x}^{(x-1)-}$, probably in the form of $\mathrm{TaO}_{2} \mathrm{~F}_{4}^{3-}$. Increase in the $\mathrm{Na}_{2} \mathrm{O} / \mathrm{K}_{2} \mathrm{Ta}_{7}$ molar ratio in excess of two leads to a decrease of tantalum concentration in the melt, and precipitation of $\mathrm{KTaO}_{3}$ occurs. Both the fluoro complex and the monooxofluoro complex were reduced to metal in a single five-electron step. The fluoro complexes, in the temperature range 625 to $815^{\circ} \mathrm{C}$ with potential scan rates $<0.5 \mathrm{~V} \cdot \mathrm{s}^{-1}$, discharge quasi-reversibly, but at potential scan rates $>0.5 \mathrm{~V} \cdot \mathrm{s}^{-1}$ they discharge irreversibly. Monooxofluoro complexes discharge irreversibly at all temperatures and scan rates studied. The diffusion coefficient of the tantalum fluoro complex depends on the temperature as $\log D=-2.55-2044 / T$ with an activation energy of $39.1 \mathrm{~kJ} \cdot \mathrm{mol}^{-1}$. For the tantalum monooxofluoro complex the dependence is $\log D=-2.35-2293 / T$ with an activation energy of $43.9 \mathrm{~kJ} \cdot \mathrm{mol}^{-1}$.

From the time of Senderoff et al. ${ }^{1}$ who studied the electroreduction of $\mathrm{K}_{2} \mathrm{TaF}_{7}$ in the LiF-NaF-KF [46.5, 11.5, 42.0 mole percent (m/o)] eutectic melt called FLINAK, extensive investigations of the mechanism of the reduction of tantalum ions in fluoride melts have been carried out, ${ }^{2-7}$ with two distinct mechanisms being suggested: $(i)$ that the process proceeds in two sequential steps ${ }^{1,3}$

$$
\begin{aligned}
& \mathrm{Ta}(\mathrm{V})+3 e^{-} \rightleftharpoons \mathrm{Ta}(\mathrm{II}) \\
& \mathrm{Ta}(\mathrm{II})+2 e^{-} \rightarrow \mathrm{Ta}(0)
\end{aligned}
$$

and (ii) that the process is one step ${ }^{4,5,8}$

$$
\mathrm{Ta}(\mathrm{V})+5 e^{-} \rightarrow \mathrm{Ta}(0)
$$

A parallel investigation using the analogous chloridefluoride melt $\left(\mathrm{KCl}-\mathrm{KF}-\mathrm{K}_{2} \mathrm{TaF}_{7}\right)$, which was titrated with tantalum pentoxide, gave the stoichiometry of the ligand substitution reaction and the effect of the oxide ions on the mechanism of the cathodic process was demonstrated. Oxofluoride melts may be of considerable practical interest but the electrochemical behavior of tantalum oxofluoro complexes, formed in fluoride melts containing oxide ions, ${ }^{9-11}$ is still unknown. However, tantalum reduction has been studied in molten $\mathrm{Na}_{3} \mathrm{AlF}_{6}$ containing $\mathrm{Ta}_{2} \mathrm{O}_{5}$ or $\mathrm{NaTaO}_{3}$ using chronopotentiometry. ${ }^{12}$ In both cases $\mathrm{Ta}(\mathrm{V})$ ions were reduced to metal in a single reversible five-electron step.

The aim of the present investigation was an understanding of the nature of the tantalum reduction process in FLINAK $-\mathrm{K}_{2} \mathrm{TaF}_{\bar{\gamma}}$ melts and of the effect of the oxide ions on the mechanism of this process.

\section{Experimental}

Alkali metal fluorides were purified either as described previously ${ }^{13}$ or by zone-refining. The voltammetric characteristics of a zone-refined melt are given in Fig. 1. In both cases the voltammograms had anodic waves corresponding to the oxidation of oxide to oxygen, which is followed by the chemical oxidation of carbon to $\mathrm{CO}$ and $\mathrm{CO}_{2}{ }^{14}$ The effect of this on the redox reactions of $\mathrm{Ta}(\mathrm{V})$ is discussed later.

$\mathrm{K}_{2} \mathrm{TaF}_{7}$ was prepared from high purity tantalum hydroxide by dissolving in hydrofluoric acid, precipitating with aqueous potassium chloride, followed by subsequent re-

* Electrochemical Society Active Member. crystallization from $\mathrm{HF}$ solution, washing with ethanol and drying in vacuum at 80 to $90^{\circ} \mathrm{C}$. The transparent $\mathrm{K}_{2} \mathrm{TaF}_{7}$ crystals obtained were packed in hermetically sealed polyethylene containers. The product was sensitive to atmospheric moisture which caused hydrolysis and loss of transparency. $\mathrm{Na}_{2} \mathrm{O}$ (Aldrich (98 weight percent (w/o)) was used without additional purification.

A Schlumberger potentiostat Model 1286 or a potentiostat PI-50-1.1. with PDA-1 potentiometer and S9-8 oscilloscope were used in the linear sweep voltammetry measurements. The electrochemical cells and the experimental technique have been described earlier. ${ }^{13,15}$

The experiments were carried out in three-electrode cells where glassy carbon served both as a container for the electrolyte and as a counterelectrode. The potentials were measured against platinum or glassy carbon quasi-reference electrodes. To obtain more reliable potential values an $\mathrm{Ag} / \mathrm{NaCl}-\mathrm{KCl}-\mathrm{AgCl}(2 \mathrm{w} / \mathrm{o})$ reference electrode was used. The Nernstian behavior of this electrode has been demon-

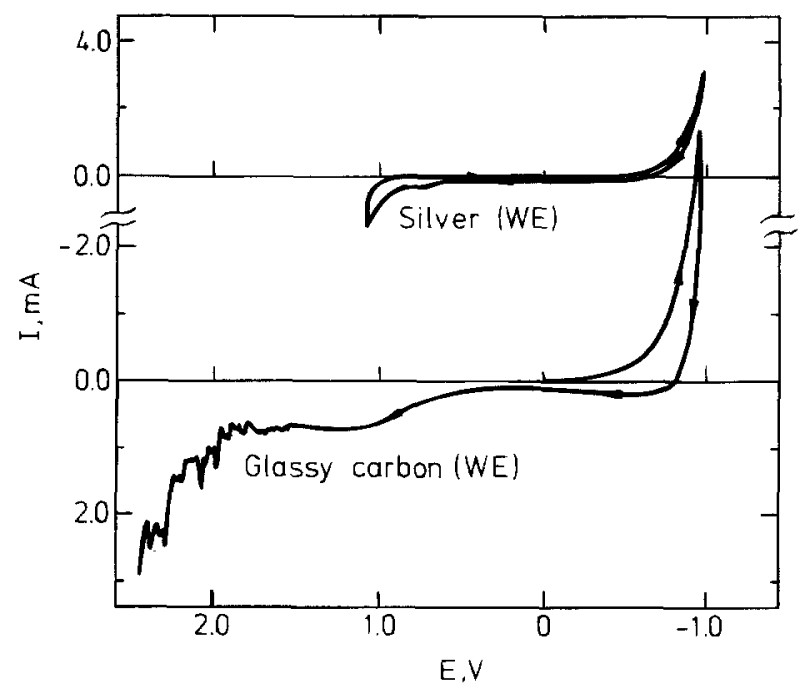

Fig. 1. Linear sweep voltammogram of a FLINAK background melt, temperature $T=708^{\circ} \mathrm{C}$, scan rate $0.1 \mathrm{~V} \cdot \mathrm{s}^{-1}$, platinum quasi-reference electrode. Working electrodes: silver electrode, $A_{A G}=0.57 \mathrm{~cm}^{2}$, and glassy carbon (GC) electrode, $A_{G C}=0.22 \mathrm{~cm}^{2}$. Oxide concentration: $\mathrm{C}_{\mathrm{O}^{2}}=2.4 \cdot 10^{-3} \mathrm{~m} / \mathrm{o}$. 


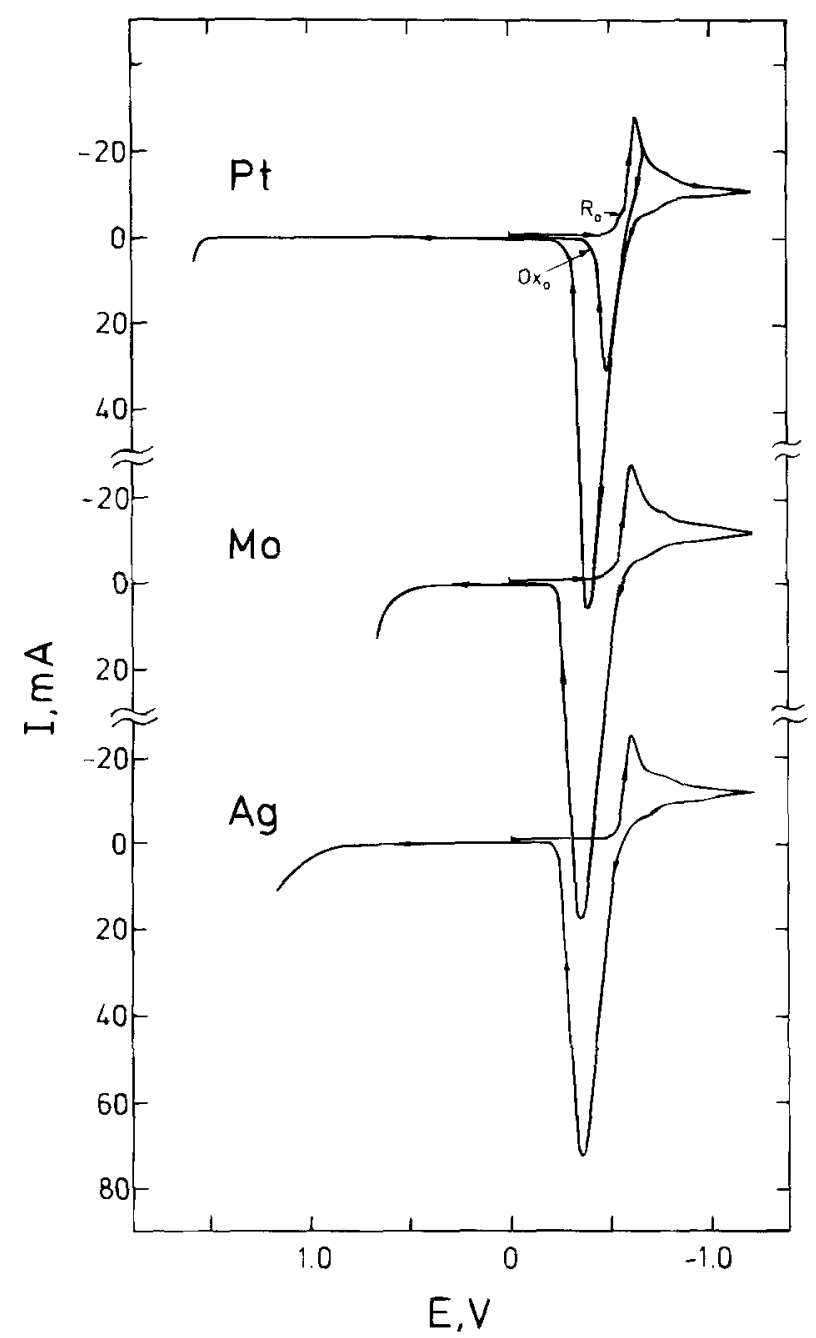

Fig. 2. Voltammograms of FLINAK- $\mathrm{K}_{2} \mathrm{TaF}_{7}$ melts, $T=710^{\circ} \mathrm{C}$, scan rate $0.1 \mathrm{~V} \cdot \mathrm{s}^{-1}$, platinum quasi-reference electrode. Various working electrodes: molybdenum, $A_{M_{0}}=0.32 \mathrm{~cm}^{2} ;$ platinum, $A_{p_{t}}=0.35 \mathrm{~cm}^{2}$; silver, $A_{\mathrm{Ag}}=0.30 \mathrm{~cm}^{2} . C_{\mathrm{K}_{2} \mathrm{Taf} 7}=0.237 \mathrm{~m} / \mathrm{o}$.

strated in $\mathrm{KCl}-\mathrm{KF}-\mathrm{K}_{2} \mathrm{TaF}_{7}$ chloride-fluoride melts ${ }^{8}$ and in $\mathrm{CsCl}-\mathrm{KCl}-\mathrm{NaCl}-\mathrm{K}_{2} \mathrm{TaF}_{7}$-melts. ${ }^{15}$ When this reference electrode was used, the potentials measured were 460 to $470 \mathrm{mV}$ more negative than when the platinum quasi-reference electrode was used. However, the $\mathrm{Ag} / \mathrm{AgCl}$ reference electrode worked only in a limited region of the electrolytes studied here. When it was possible, the potentials were measured vs. all three reference electrodes.

Since interactions between tantalum species and the electrode materials, ${ }^{4}$ (glassy carbon, platinum, molybdenum, and silver) are possible, preliminary experiments were carried out. Cathodic curves on glassy carbon electrodes had no clearly defined peaks in the potential range of $\mathrm{Ta}(\mathrm{V})$ reduction. Thus these electrodes were used only to record anodic curves of oxide oxidation during titration of the melt with sodium oxide, to determine the residual content of oxide in the background electrolyte concerning the residual content of oxide ions and the change in oxide concentration following $\mathrm{K}_{2} \mathrm{TaF}_{7}$ additions.

Typical voltammograms of FLINAK-K $\mathrm{TaF}_{7}$ melts obtained with Pt, Mo, and Ag electrodes are given in Fig. 2. The cathodic part of the voltammograms obtained with the platinum electrode are shown in more detail in Fig. 3 . Besides the main peaks discussed below, a shoulder $\left(R_{0}\right)$ was seen only when a platinum electrode was used (Fig. 2). The wave $R_{0}$ was not well defined even at high $\mathrm{K}_{2} \mathrm{TaF}_{\eta}$ content and its limiting current did not depend on the $\mathrm{K}_{2} \mathrm{TaF}_{7}$ concentration (Fig. 3). However the height of this wave was affected by the temperature; it disappeared when the temperature was lower than $630^{\circ} \mathrm{C}$, but appeared again with increase in temperature. These observations and the absence of the wave $R_{0}$ with Mo and Ag electrodes suggest intermetallic Pt-Ta compounds formation, cf. the Pt-Ta phase diagram. ${ }^{16}$ Thus molybdenum and silver electrodes are preferable to platinum electrodes, because tantalum forms a continuous series of solid solutions with molybdenum, whereas it does not interact with silver in the solid state. ${ }^{17}$ As a result only an insignificant distortion of the initial section was seen on the polarization curve with Mo, and voltammograms obtained on silver electrodes had no trace of interaction between silver and tantalum. Hence silver working electrodes were used exclusively in our study.

\section{Results and Discussion}

The cyclic voltammogram shape, with additions of less than $0.1 \mathrm{~m} / \mathrm{o}$ of $\mathrm{K}_{2}{ }^{2} \mathrm{TaF}_{7}$ to FLINAK, was not reproducible. This can be explained as the effect of oxide impurities in the melt, due either to nonreproducible purification of the salts or to contact of the melt with oxide ceramics. Use of insufficiently purified FLINAK and low $\mathrm{K}_{2} \mathrm{TaF}_{7}$ concentrations results in cyclic voltammograms with the shape as curve $\mathrm{c}$ in Fig. 4 , where the cathodic peaks $R_{2}$ and $R_{3}$ on the voltammograms (with corresponding anodic $\mathrm{Ox}_{2}$ and $\mathrm{Ox}_{3}$ peaks) are seen but only increase of the $\mathrm{K}_{2} \mathrm{TaF}_{7}$ concentration increases the size of peak $R_{1}$ (curve $\mathrm{b}$ in Fig. 4). If $\mathrm{K}_{2} \mathrm{TaF}_{7}$ contains minimal amounts of oxide impurity it is possible, by increasing its concentration to 0.4 to $0.5 \mathrm{~m} / \mathrm{o}$, to obtain a voltammogram showing only the cathodic peak $R_{1}$ and the corresponding anodic peak $\mathrm{Ox}_{1}$ (curve a Fig. 4). As was stated earlier, ${ }^{15}$ this made complications for the interpretation of the cathodic peaks, since they could be assigned either to different steps in the reduction of one $\mathrm{Ta}(\mathrm{V})$ fluoro complex to metal, or to the reduction of two tantalum species (a fluoro complex and an oxofluoro complex). Here potentiostatic electrolysis at potentials corresponding to the first wave resulted in deposition of metallic tantalum on the cathode, just as in mixed chloride fluoride melts. ${ }^{8,15}$

Titration of tantalum in halide melts with tantalum pentoxide was reported by Konstantinov et $a l^{8}{ }^{8}$ It explained the nature of the voltammogram peaks, the reduction mechanism and also determined the stoichiometry of the ligand displacement reactions of the fluoro complexes initially present. An alternative approach is to titrate with sodium monoxide where the complication of changes in tantalum concentration does not occur. Thus Raman spectroscopy has been used recently for investigation ${ }^{11}$ of the

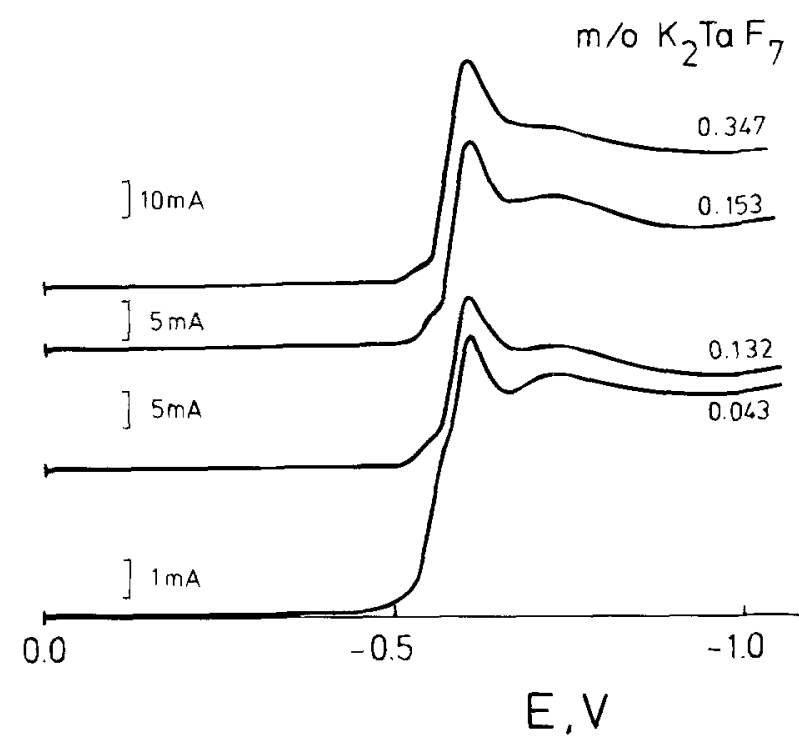

Fig. 3. Voltammograms of FLINAK- $\mathrm{K}_{2} \mathrm{TaF}_{7}$ melts, $T=708^{\circ} \mathrm{C}$, scan rate $0.05 \mathrm{~V} \cdot \mathrm{s}^{-1}$, platinum quasi-reference electrode. Platinum working electrode, $A_{\mathrm{Pt}}=0.31 \mathrm{~cm}^{2} ; C_{\mathrm{K}_{2} \text { Taf } 7}=0.043,0.132,0.153$, and $0.347 \mathrm{~m} / \mathrm{o}$. 


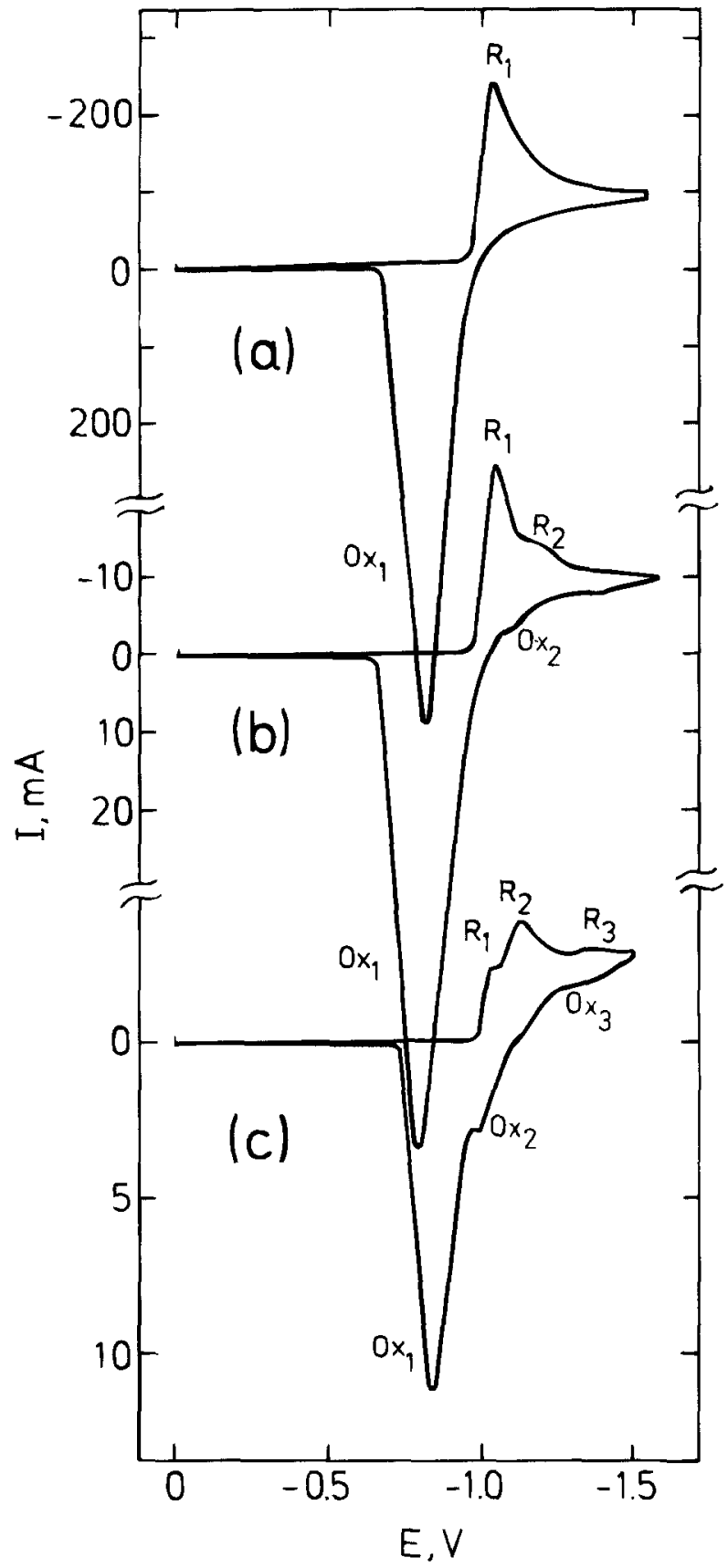

Fig. 4. Variation of cyclic voltammetric curves shape depending on the purity of the melt, $T=708^{\circ} \mathrm{C}$, scan rate $0.1 \mathrm{~V} \cdot \mathrm{s}^{-}, \mathrm{Ag} / \mathrm{AgCl}$ reference electrode. Silver working electrodes: (a) $A_{A g}=0.57 \mathrm{~cm}^{2}$, $\mathrm{C}_{\mathrm{K}_{2} \mathrm{TaF} 7}=0.526 \mathrm{~m} / \mathrm{o} ;$ (b) $A_{\mathrm{Ag}}=0.31 \mathrm{~cm}^{2}, \mathrm{C}_{\mathrm{K}_{2} \text { Taf7 }}=0.106 \mathrm{~m} / \mathrm{o} ;(\mathrm{c}) A_{\mathrm{Ag}}=$ $0.42 \mathrm{~cm}^{2}, \mathrm{C}_{\mathrm{K}_{2} \mathrm{TaF} 7}=0.0206 \mathrm{~m} / \mathrm{o}$.

FLINAK- $\mathrm{K}_{2} \mathrm{TaF}_{7}$-melt structure during titration with sodium monoxide.

In the present work we also used sodium monoxide additions to follow the change in shape of the cathodic part of the voltammograms and the peak height. This work also involved estimation of the height of the oxidation peaks of oxide ions, using a glassy carbon indicator electrode, to determine the decomposition of the complexes formed in the oxofluorotantalate-containing melts. Earlier White ${ }^{18}$ found that the height of these peaks was directly proportional to the amount of oxide added to the melt, and thus determined the oxide concentration.

It is apparent from Fig. 5 (curve a1) that the starting electrolyte with $0.406 \mathrm{~m} / \mathrm{o}$ of $\mathrm{K}_{2} \mathrm{TaF}_{7}$ already contained a small quantity of oxide ions. This was confirmed by the shape of the cathodic part of the voltammograms obtained with a silver electrode, (Fig. 5 , curve b1). Here, besides the

main reduction peak of the $\mathrm{TaF}_{7}^{2-}$ complex ${ }^{9-11}$ to metal, a second minor peak was present. The latter wave corresponding to discharge of oxofluoro complexes. Addition of small amounts of sodium oxide to the molten FLINAK$\mathrm{K}_{2} \mathrm{TaF}_{7}$ melt (Fig. 5b 2-6) resulted in lowering the first peak, $R_{1}$, and the growth of the second and third peaks, $R_{2}$ and $R_{3}$. The anodic curves (Fig. 5a 2-6) showed a corresponding increase in the oxide oxidation wave. A plot of the peak current of oxide ion oxidation $v s$. the molar ratio $\mathrm{Na}_{2} \mathrm{O} / \mathrm{K}_{2} \mathrm{TaF}_{7}$ (Fig. 6) was used as a calibration curve to determine the initial oxide content in the melt. The concentration of oxide ions in this initial melt was $0.029 \mathrm{~m} / \mathrm{o}$ by extrapolation. A plot of the first cathodic peak current against the $\mathrm{Na}_{2} \mathrm{O} / \mathrm{K}_{2} \mathrm{TaF}_{7}$ ratio (Fig. 7a) was linear and allowed estimation of the stoichiometry of ligand displacement, Eq. 4, (taking into account the initial oxide content)

$$
\mathrm{K}_{2} \mathrm{TaF}_{7}+\mathrm{Na}_{2} \mathrm{O} \rightleftharpoons \mathrm{K}_{2} \mathrm{TaOF}_{5}+2 \mathrm{NaF}
$$

since the height of the first peak reached zero at a molar ratio of $\mathrm{Na}_{2} \mathrm{O} / \mathrm{K}_{2} \mathrm{TaF}_{7}$ close to unity.

When the sodium oxide concentration in the melt exceeded a molar ratio of $\mathrm{Na}_{2} \mathrm{O} / \mathrm{K}_{2} \mathrm{TaF}_{7}=1$, there was proportional growth of the anodic oxide oxidation waves (Fig. 5 a 7-11). The corresponding cathodic curves (Fig. 5b 7-11) showed proportional lowering of the discharge wave of the - monooxofluoro complexes and growth of the more negative third peak. This variation of anodic and cathodic waves stopped when the $\mathrm{Na}_{2} \mathrm{O} / \mathrm{K}_{2} \mathrm{TaF}_{7}$ molar ratio reached a value of 2.01 (including initial oxide content, Fig. 7b) suggesting Eq. 5

$$
\mathrm{K}_{2} \mathrm{TaF}_{7}+2 \mathrm{Na}_{2} \mathrm{O} \rightleftharpoons \mathrm{K}_{2} \mathrm{TaO}_{2} \mathrm{~F}_{3}+4 \mathrm{NaF}
$$

(a)

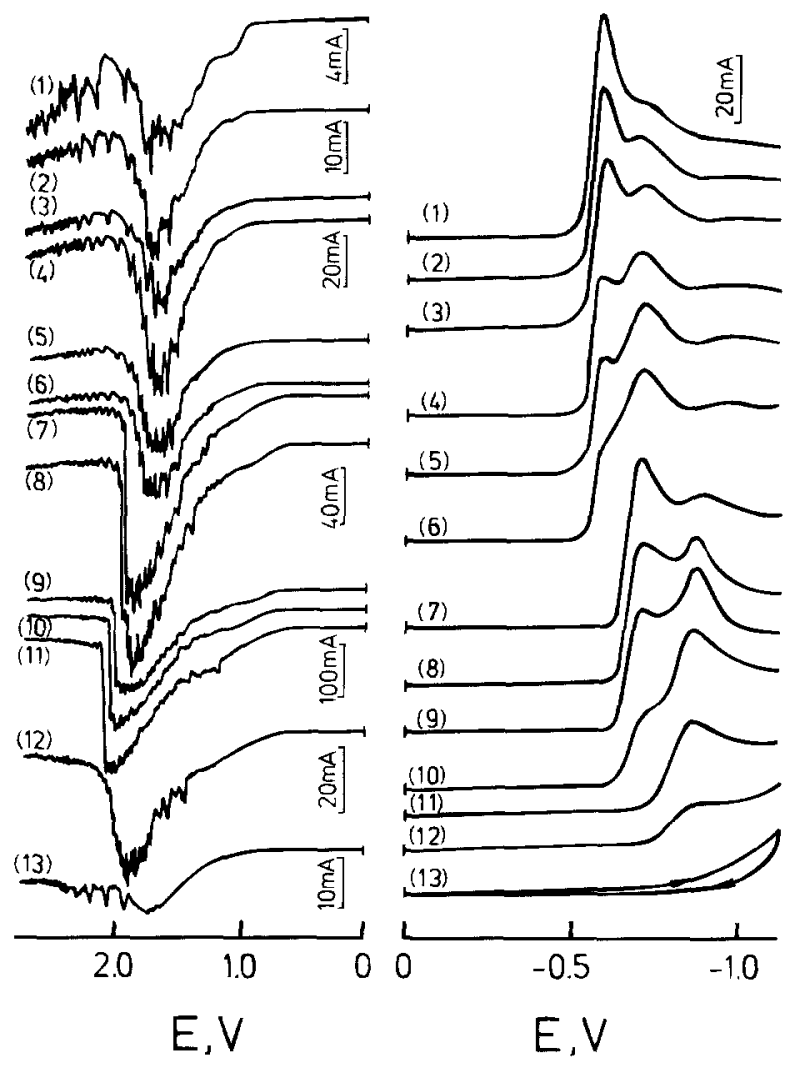

Fig. 5 (a) Variation of $\mathrm{O}^{2-}$ oxidation anode waves and (b) tantalum reduction cathode waves in FLNAK- $\mathrm{K}_{2} \mathrm{TaF}_{7}-\mathrm{NaO}_{2}$ melts at $\mathrm{T}=710^{\circ} \mathrm{C}$ with scan rate in all cases $0.1 \mathrm{~V} \cdot \mathrm{s}^{-1}$, and with $\mathrm{Pt}$ quasi-reference electrode. Working electrodes: (a) glassy carbon, $A_{G C}=0.25 \mathrm{~cm}^{2}$; (b) silver, $A_{\mathrm{Ag}}=0.42 \mathrm{~cm}^{2} . \mathrm{K}_{2} \mathrm{TaF}_{7}$ initial concentration $0.406 \mathrm{~m} / \mathrm{o}$ and different $\mathrm{Na}_{2} \mathrm{O} / \mathrm{K}_{2} \mathrm{TaF}_{7}$ ratio: (1) 0 ; (2) 0.135 ; (3) 0.214 ; (4) 0.373 ; (5) $0.470 ;(6) 0.518 ;(7) 0.942 ;(8) 1.140 ;(9) 1.250 ;(10) 1.545 ;(11)$ $1.947 ;(12) 2.581 ;$ (13) 3.034 . 


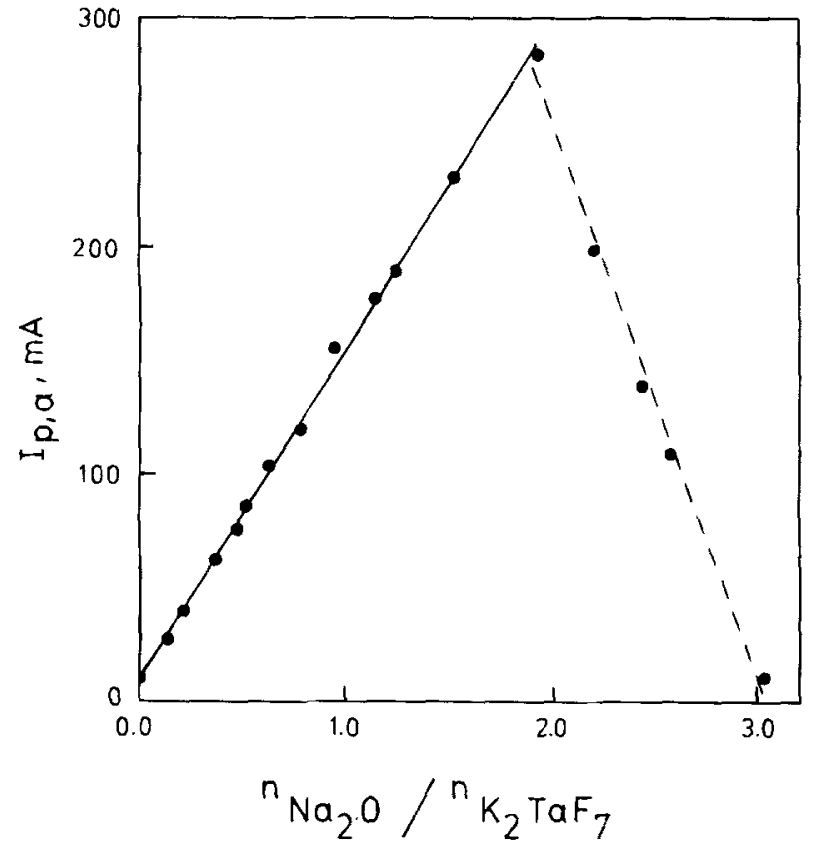

Fig. 6. Anodic current of $\mathrm{O}^{2-}$ oxidation peak as a function of molar ratio $\mathrm{Na}_{2} \mathrm{O} / \mathrm{K}_{2} \mathrm{TaF}_{7}$ in FLINAK- $\mathrm{K}_{2} \mathrm{TaF}_{7}-\mathrm{Na}_{2} \mathrm{O}$ melts, $T=710^{\circ} \mathrm{C}, \mathrm{A}_{\mathrm{GC}}=$ $0.26 \mathrm{~cm}^{2} ; C_{\mathrm{K}_{2} \mathrm{or}_{7}}^{\text {int }}=0.406 \mathrm{~m} / \mathrm{o}$.

or, assuming the earlier formation of $\mathrm{K}_{2} \mathrm{TaOF}_{5}$ (Eq. 4)

$$
\mathrm{K}_{2} \mathrm{TaOF}_{5}+\mathrm{Na}_{2} \mathrm{O}=\mathrm{K}_{2} \mathrm{TaO}_{2} \mathrm{~F}_{3}+2 \mathrm{NaF}
$$

Unfortunately, voltammetry does not determine the accurate stoichiometry of the complexes participating in the electrode reactions. Thus the dioxofluoro complexes formed in the molten state as a result of the chemical interaction should be written as $\mathrm{TaO}_{2} \mathrm{~F}_{x}^{(x-1)^{-}}$, ( $x$ was proposed previously to be equal to $4,{ }^{11}$ the compounds $\mathrm{K}_{3} \mathrm{TaO}_{2} \mathrm{~F}_{4}{ }^{19}$ and $\mathrm{KTaO}_{2} \mathrm{~F}_{2}{ }^{20}$ also have been reported).

Further addition of $\mathrm{Na}_{2} \mathrm{O}$ in excess of a molar ratio $\mathrm{Na}_{2} \mathrm{O}$ / $\mathrm{K}_{2} \mathrm{TaF}_{7}$ equal to 2 resulted in simultaneous lowering of both the anodic and the cathodic peaks (Fig. 5a 12, b 12), but no new peaks appeared. The plot of $I_{\mathrm{p}, \mathrm{a}} v s . \mathrm{Na}_{2} \mathrm{O} / \mathrm{K}_{2}{ }^{\mathrm{Ta}} \mathrm{F}_{7}$ gave a line crossing the concentration axis in a point close to a value of 3 (Fig. 6). The voltammograms corresponding to this $\mathrm{Na}_{2} \mathrm{O} / \mathrm{K}_{2} \mathrm{TaF}_{7}$ ratio (Fig. 5a 13 and b 13) were similar to the background electrolyte voltammograms suggesting an absence of tantalum in the melt. The bottom of the solidified electrolyte after an experiment contained solid $\mathrm{KTaO}_{3}$ (identified by XRD), i.e.

$$
\begin{aligned}
(x-1) \mathrm{K}^{+}+\mathrm{TaO}_{2} \mathrm{~F}_{x}^{(x-1)-}+ & \mathrm{O}^{2-} \\
& \rightarrow \mathrm{KTaO}_{3}+x \mathrm{~F}^{-}+(x-2) \mathrm{K}^{+}
\end{aligned}
$$

$\mathrm{Na}_{2} \mathrm{O}$ addition in excess of a molar ratio $\mathrm{Na}_{2} \mathrm{O} / \mathrm{K}_{2} \mathrm{TaF}_{7}$ of 3 gave an increase in the anodic currents. This is probably due to oxidation of oxide ions formed by the dissolution of excess $\mathrm{Na}_{2} \mathrm{O}$.

As mentioned above, while the first cathodic peak on the voltammogram of $\mathrm{K}_{2} \mathrm{TaF}_{7}$ containing FLINAK melts corresponding to the reduction to the metal from $\mathrm{TaF}_{7}^{2-}$ fluoro complexes, the corresponding anodic peak for metal dissolution, $\mathrm{Ox}_{1}$, is shown in Fig. $4 \mathrm{a}$. The nature of this tantalum reduction process was studied using the dependence of the linear voltammogram parameters on the potential sweep rate (Fig. $8 \mathrm{a}, \mathrm{b}$ ) and the concentration of tantalum ions (Table I). The peak current $\left(I_{\mathrm{p}, 1}\right)$ is linearly proportional to the $\mathrm{K}_{2} \mathrm{TaF}_{7}$ concentration in the melt. For temperatures from 625 to $815^{\circ} \mathrm{C}$ the peak potential $E_{\mathrm{p}, 1}$ depended on the logarithm of the scan rate $(\log v)$ (Fig. $8 \mathrm{~b})$, shifting to the negative potential region with increasing scan rate. At scan rates $<0.5 \mathrm{~V} \cdot \mathrm{s}^{-1}$ this plot is nonlinear, whereas at $v \geq 0.5 \mathrm{~V}$. $\mathrm{s}^{-1}$ the peak potential is linearly dependent on $\log v$.
Figure 8a also demonstrates the complex character of the peak current change at scan rates $<0.5 \mathrm{~V} \cdot \mathrm{s}^{-1}$, in that $I_{\mathrm{p}, 1}$ was not linearly dependent on the square root of the potential scan rate, but $I_{p, 1} / v^{1 / 2}$ became smaller with the increase in $\log v$. At rates of 0.5 to $2.0 \mathrm{~V} \cdot \mathrm{s}^{-1}$ the $I_{\mathrm{p}, 1} / v^{1 / 2}$ ratio became constant.

There is a convenient and simple criterion to determine process reversibility: the difference between peak and halfpeak potentials which for reversible processes is described by the following expression

$$
E_{\mathrm{p} / 2}-E_{\mathrm{p}}=2.20 R T / n F
$$

For potential scan rates $<0.5 \mathrm{~V} \cdot \mathrm{s}^{-1}$ the number of electrons calculated using this equation from the voltammograms exceeded a value equal to 5 . However for irre-
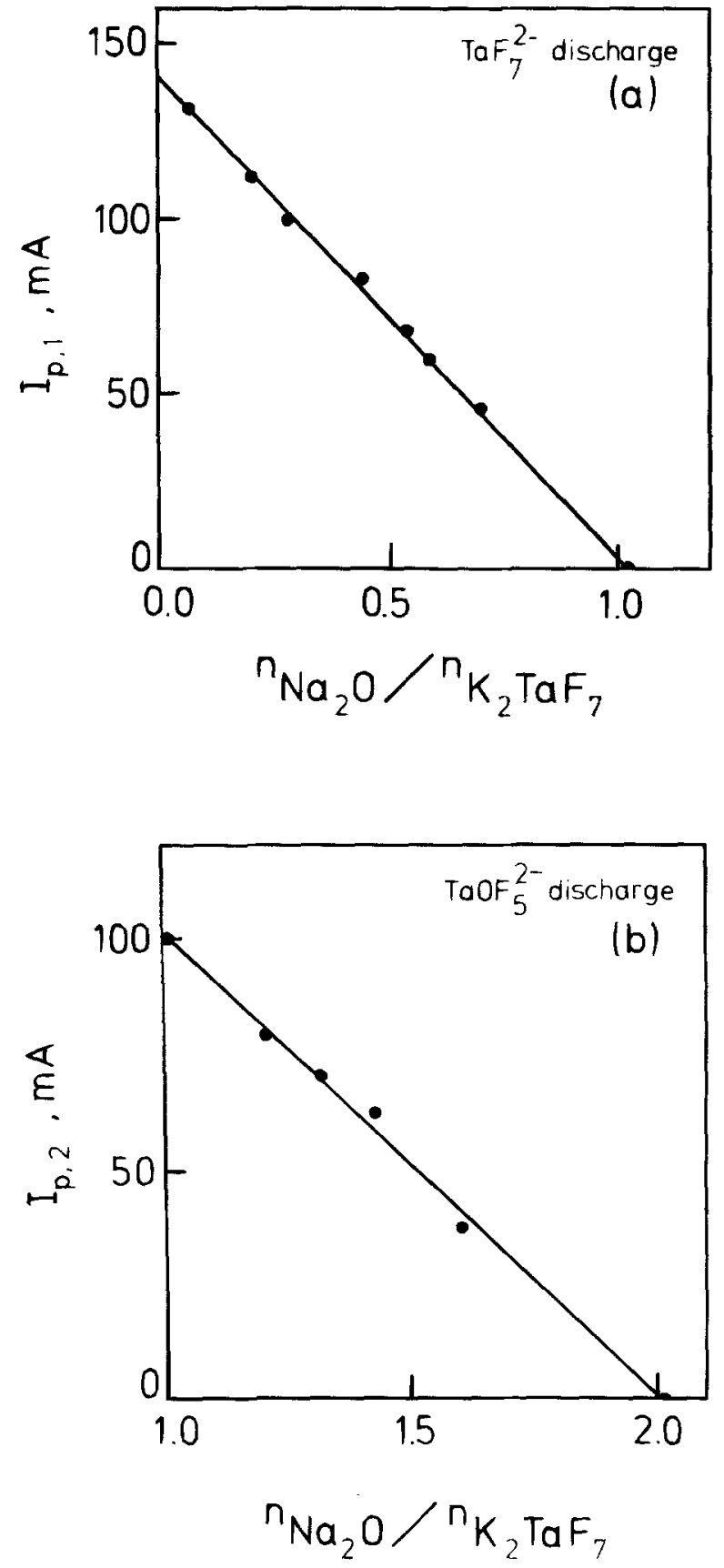

Fig. 7. Tantalum reduction peak currents as a function of the $\mathrm{Na}_{2} \mathrm{O} / \mathrm{K}_{2} \mathrm{TaF}_{7}$ molar ratio in FLINAK- $\mathrm{K}_{2} \mathrm{TaF}_{7}-\mathrm{Na}_{2} \mathrm{O}$ melt, $T=710^{\circ} \mathrm{C}$ scan rate $0.1 \mathrm{~V} \cdot \mathrm{s}^{-1} \cdot A_{\mathrm{Ag}}=0.42 \mathrm{~cm}^{2}$; (a) $\mathrm{TaF}_{7}^{2-}$ discharge; (b) TaOF $\mathrm{Ta}_{5}^{2-}$ discharge; $C_{\mathrm{K}_{2} \mathrm{TaF}_{7}}^{\text {init }}=0.406 \mathrm{~m} / \mathrm{o}$. The oxide contents have been corrected with an amount corresponding to $0.029 \mathrm{~m} / \mathrm{o}$ on the basis of the measurements shown in Fig. 6. 

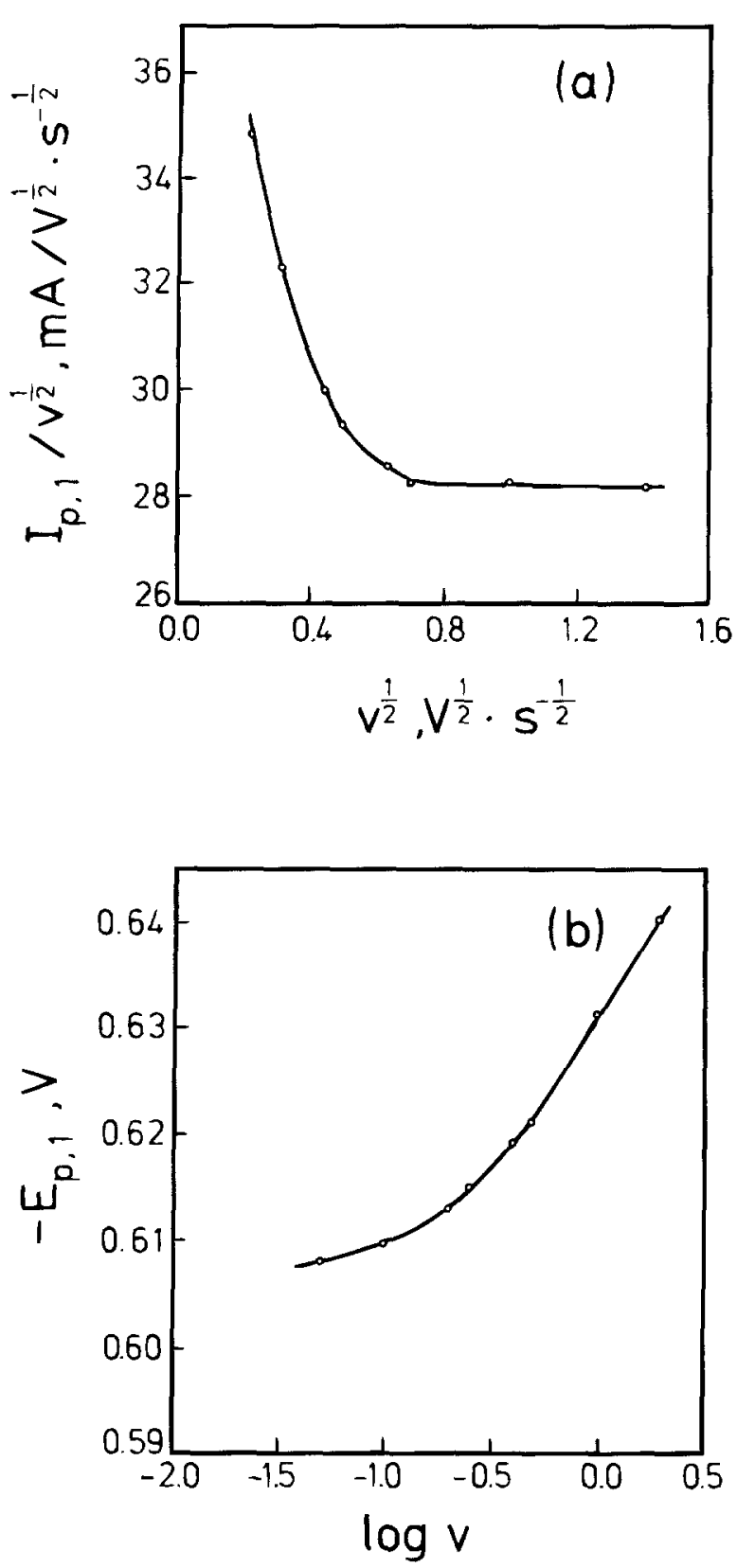

Fig. 8. Scan rate effect on (a) peak current and (b) peak potential of the $\mathrm{TaF}_{7}^{2-}$ reduction process, $T=710^{\circ} \mathrm{C}$, platinum quasi-reference electrode. (a) $A_{\mathrm{Ag}}=0.31 \mathrm{~cm}^{2} ;$ (b) $A_{\mathrm{Ag}}=0.036 \mathrm{~cm}^{2} ; \mathrm{C}_{\mathrm{K} 2 \mathrm{TaF}}=$ $0.043 \mathrm{~m} / \mathrm{o}$.

versible electrode processes another equation should be used $^{21}$

$$
E_{\mathrm{p} / 2}-E_{\mathrm{p}}=1.857 R T / \alpha n_{\alpha} F
$$

but $\alpha n_{\alpha}$ calculated for the rate range 0.05 to $0.4 \mathrm{~V} \cdot \mathrm{s}^{-1}$ was $>5$, though the transfer coefficient $\alpha$ was always smaller than unity.

These considerations, together with the peak current and the peak potential dependence on concentration and potential scan rate, show that the reduction of $\mathrm{Ta}(\mathrm{V})$ fluoro complexes to the metal in the scan rate interval 0.05 to

Table 1. TaF $F_{7}^{2-}$ reduction peak current related to concentration of $\mathrm{K}_{2} \mathrm{TaF}_{7 .}\left(\mathrm{T}=710^{\circ} \mathrm{C}\right.$, scan rate $\left.0.1 \mathrm{~V} \cdot \mathrm{s}^{-1}, A_{\mathrm{Ag}}=0.57 \mathrm{~m}^{2}\right)$.

\begin{tabular}{llllllllll}
\hline $\begin{array}{c}\mathrm{C} \\
\mathrm{K}_{2} \mathrm{TaF}_{7} \\
(\mathrm{~m} / \mathrm{o})\end{array}$ & 0.06 & 0.11 & 0.19 & 0.25 & 0.33 & 0.42 & 0.53 & 0.63 \\
\hline$I_{\mathrm{p} 1}(\mathrm{~mA}) 21$ & 45 & 88 & 114 & 147 & 194 & 242 & 290
\end{tabular}

Table II. Kinetic parameters of $\mathrm{TaF}_{7}^{2-}+5 e^{-} \rightarrow \mathrm{Ta}+7 \mathrm{~F}^{-}$process (FLINAK-K TaF $_{7}$ melt, scan rate $=0.5 \mathrm{~V} \cdot \mathrm{s}^{-1}, A_{\mathrm{Ag}}=0.42 \mathrm{~cm}^{2}$ ).

\begin{tabular}{ccccc}
\hline & $\begin{array}{c}\text { Peak } \\
\text { current } \\
I_{\mathrm{p}, 1} \\
(\mathrm{~mA})\end{array}$ & $\begin{array}{c}\mathrm{C} \cdot 10^{5} \\
\mathrm{~K}_{2} \mathrm{TaF}_{7} \\
\left(\mathrm{~mol}^{-3} \mathrm{~cm}^{-3}\right)\end{array}$ & $\alpha n_{\alpha}$ & $\begin{array}{c}\mathrm{D} \cdot 10^{5} \\
\left(\mathrm{~cm}^{2} \cdot \mathrm{s}^{-1}\right)\end{array}$ \\
\hline 815 & 226.0 & 7.90 & 3.87 & 3.70 \\
725 & 192.0 & 8.36 & 3.50 & 2.57 \\
672 & 170.2 & 8.49 & 3.36 & 1.93 \\
625 & 147.5 & 8.61 & 3.19 & 1.41 \\
572 & 132.7 & 8.74 & 2.97 & 1.12
\end{tabular}

$0.4 \mathrm{~V} \cdot \mathrm{s}^{-1}$ was only quasi-reversible, (i.e., the rate of the diffusion step approached the rate of the electron-transfer step). Further increase of scan rate above $0.5 \mathrm{~V} \cdot \mathrm{s}^{-1}$ resulted in the transformation of the quasi-reversible process into an irreversible one. Lowering of temperature effected the process in the same way; at temperatures lower than $580^{\circ} \mathrm{C}$ the process became irreversible at all scan rates studied. In contrast it has been found previously for mixed chloride/ fluoride melts ${ }^{8,22}$ that the reduction of $\mathrm{TaF}_{7}^{2-}$ to metal was reversible. Thus when the alkali fluoride content in the mixed systems is increased to very high values (such as in FLINAK) the kinetics of the process must be changed to irreversible.

The mathematical treatment of voltammograms of a quasi-reversible process is complicated, ${ }^{23}$ thus only the data obtained at irreversible conditions (i.e., at $v \geq 0.5 \mathrm{~V}$. $\mathrm{s}^{-1}$ ) is considered here, the transfer coefficient $\alpha$ is calculated from the slope of the linear section of the $E_{p} v s . \log v$ plot (Fig. 8b) at $710^{\circ} \mathrm{C}$ using the following equation ${ }^{24}$

$$
K=2.303 R T / 2 \alpha n_{\alpha} F
$$

where $K$ is a slope and $n_{c x}$ is number of electrons. ${ }^{24}$ For $983 \mathrm{~K}$ $\alpha n_{\alpha}$ equals 3.09 , and since $n$ must be 5 (electrolysis at poten-
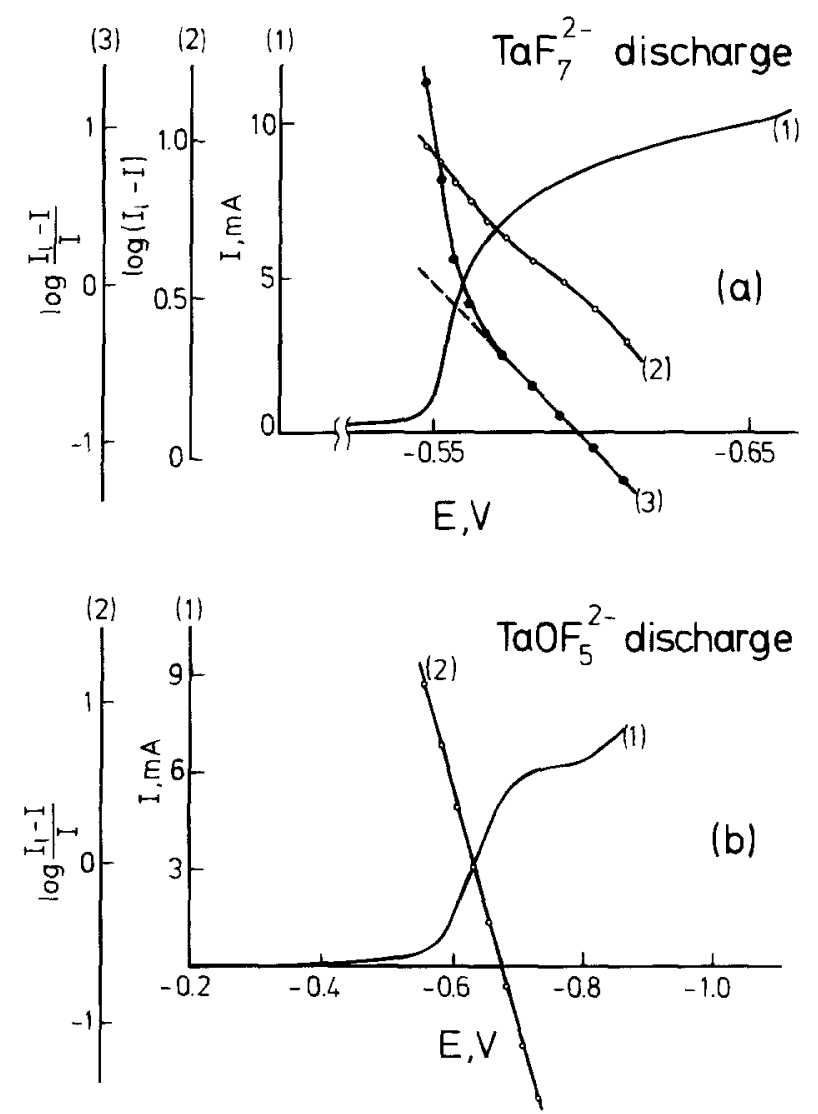

Fig. 9. Stationary voltammogram of tantalum reduction, $T=710^{\circ} \mathrm{C}$, scan rate $0.0025 \mathrm{~V} \cdot \mathrm{s}^{-1}$, platinum quasi-reference electrode. (a) $\mathrm{TaF}_{7}^{2-}$ discharge, $A_{\mathrm{Ag}}=0.57 \mathrm{~cm}^{2}, \mathrm{C}_{\mathrm{K}_{2} \mathrm{TaF}_{7}}=0.056 \mathrm{~m} / \mathrm{o}$; (b) $\mathrm{TaOF}_{5}^{2-}$, $A_{A_{g}}=0.31 \mathrm{~cm}^{2}, C_{\mathrm{K}_{2} \mathrm{Tof} 7}=0.071 \mathrm{~m} / \mathrm{o}$. 


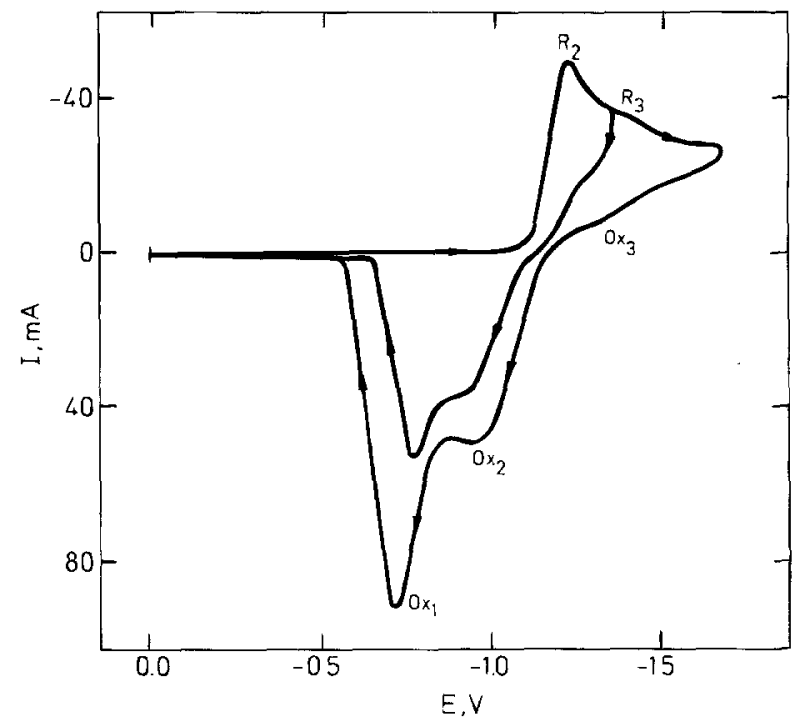

Fig. 10. Cyclic voltammogram of FLINAK- $\mathrm{K}_{2} \mathrm{TaF}_{7}-\mathrm{Na}_{2} \mathrm{O}$ melt, $T=$ $710^{\circ} \mathrm{C}$, scan rate $0.5 \mathrm{~V} \cdot \mathrm{s}^{-1}, \mathrm{Ag} / \mathrm{AgCl}$ reference. $A_{\mathrm{Ag}}=0.31 \mathrm{~cm}^{2}$. $\mathrm{C}_{\mathrm{K}_{2} \text { Jof }}=0.139 \mathrm{~m} / \mathrm{o}$. Molar ratio $\mathrm{Na}_{2} \mathrm{O} / \mathrm{K}_{2} \mathrm{TaF}_{7}=1$. The oxide content has been corrected with an amount corresponding to $0.029 \mathrm{~m} / \mathrm{o}$ on the basis of the measurements shown in Fig. 6 .

tials corresponding to this wave resulting in tantalum deposition), $\alpha$ is equal to $0.62 . \alpha n_{\alpha}$ values for temperatures from 572 to $815^{\circ} \mathrm{C}$, calculated from the difference of the peak and half-peak potentials (Eq. 9), are summarized in Table II.

With a knowledge of the $\alpha n_{\alpha}$ values, it is possible to calculate the diffusion coefficient of the Ta(V) fluoro complexes. The equation ${ }^{24}$ for an irreversible electrochemical process with deposition of an insoluble layer at the cathode is

$$
I_{\mathrm{p}}=0.496 n F \mathrm{CAD}^{1 / 2}\left(\alpha n_{\alpha} F v / R T\right)^{1 / 2}
$$

The tantalum concentration was corrected both for the initial oxide ion content in the melt, and assuming that the peak current value of the $\mathrm{Ta}(\mathrm{V}) \rightarrow \mathrm{Ta}(0)$ reduction of fluoro complexes was diminished by the amount of tantalum ions converted into monooxofluoro complexes. The temperature dependence of the logarithm of the diffusion coefficient of $\mathrm{TaF}_{7}^{2-}$ ions can then be expressed by the empirical equation

$$
\log D=-2.55-2044 / T
$$

The activation energy of diffusion determined from the slope of $\log D$ vs. $1 / T$ was $39.1 \mathrm{~kJ} \cdot \mathrm{mol}^{-1}$. All the kinetic parameters of the tantalum reduction process in fluoride melts are summarized in Table II.

Plots of $\log \left(I_{\ell}-I\right)$ vs. $E$ and $\log \left[\left(I_{\ell}-I\right) / I\right] v s . E$ (Fig. 9a) have shown that in the temperature range 600 to $815^{\circ} \mathrm{C}$, both curves are nonlinear. This also indicates that the process is quasi-reversible. In this case it is possible to calculate the coefficient $\alpha$, from a plot of $\log \left[\left(I_{\ell}-I\right) / I\right] v s$. $E$, by measuring the asymptotic slope at more negative potentials where the forward reaction is much faster than the reverse reaction..$^{21,25}$ The $\alpha$ value at $710^{\circ} \mathrm{C}$ calculated in this way is equal to 0.77 , which is similar to, but somewhat larger than, the value obtained using Eq. 10

When a $1: 1$ composition of sodium monoxide: $\mathrm{K}_{2} \mathrm{TaF}_{7}$ in FLINAK, taking into account the initial content of oxide ions, was studied, the peak due to tantalum reduction from the $\mathrm{TaF}_{7}^{2-}$ complex, $R_{1}$ seen in Fig. 4 , was completely suppressed (Fig. 10). Further, X-ray diffraction (XRD) showed that the deposit obtained during potentiostatic electrolysis at this half-wave potential consisted of metallic tantalum. Thus metallic tantalum was deposited by reduction of $\mathrm{TaOF}_{5}^{2-}$ as well as by reduction of $\mathrm{TaF}_{7}^{2-}$.

To clarify the mechanism of tantalum reduction from the $\mathrm{TaOF}_{5}^{2-}$ complex, we studied plots of the peak current $\left(I_{\mathrm{p}, 2}\right)$ and of peak potential against scan rate (Fig. $11 \mathrm{a}, \mathrm{b})$. The
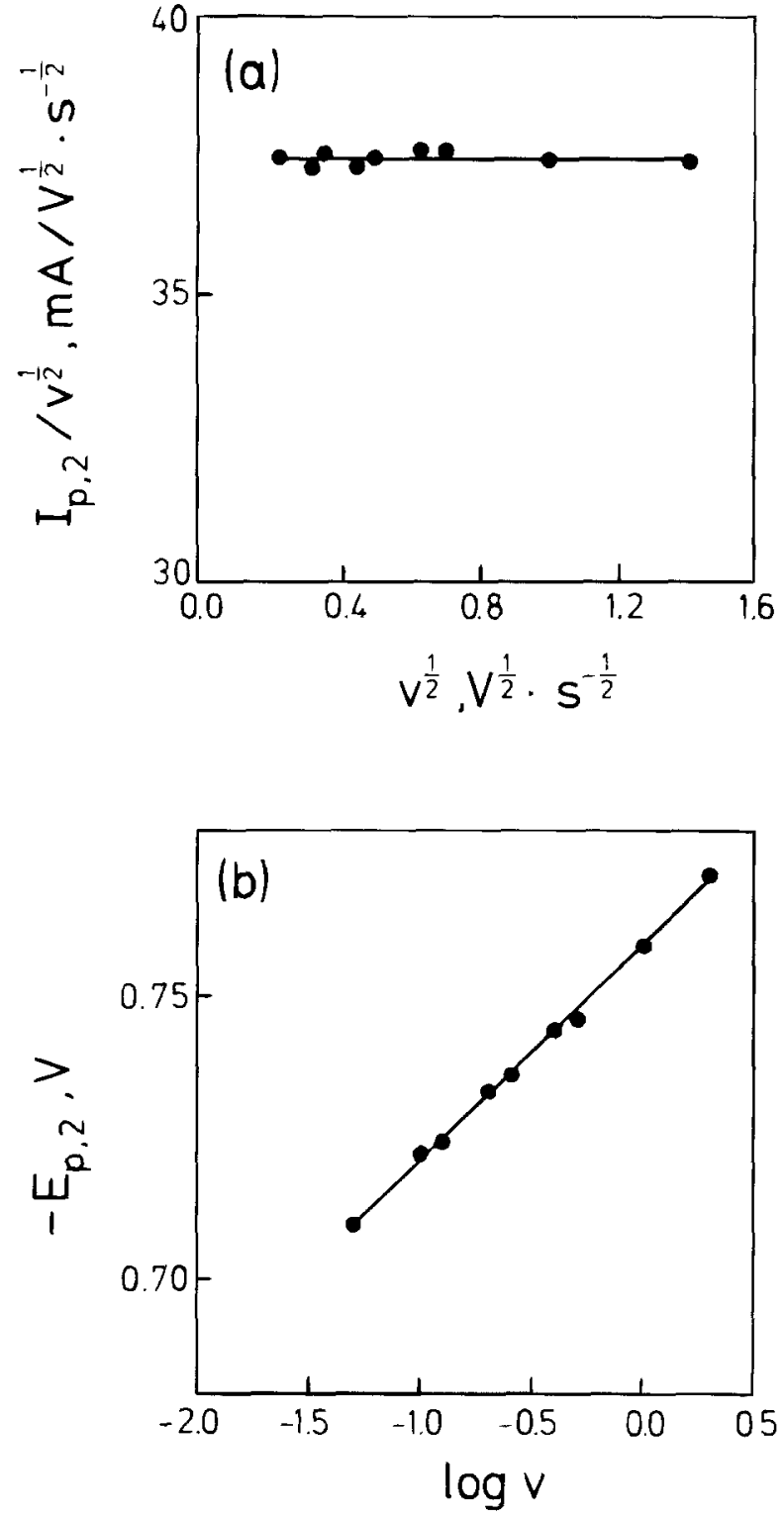

Fig. 11. Scan rate effect on (a) peak current and (b) peak potential of the TaOF ${ }_{5}^{2-}$ reduction process, $T=709^{\circ} \mathrm{C}, \mathrm{Pt}$ quasi-reference electrode. (a) $A_{\mathrm{Ag}}=0.31 \mathrm{~cm}^{2}$; (b) $A_{\mathrm{Ag}}=0.036 \mathrm{~cm}^{2} . C_{\mathrm{K}_{2} \mathrm{TaF}_{7}}=0.071 \mathrm{~m} / \mathrm{o}$. Molar ratio $\mathrm{Na}_{2} \mathrm{O} / \mathrm{K}_{2} \mathrm{TaF}_{7}=1$.

parameter $I_{\mathrm{p}, 2} / v^{1 / 2}$ was independent of $v^{1 / 2}$ in the scan rate range of 0.05 to $2.0 \mathrm{~V} \cdot \mathrm{s}^{-1}$, but the $E_{\mathrm{o}, 2}$ potential showed linear dependence on $\log v$ and shifted to the negative region with the increase in scan rate. This, as well as the fact that the peak current was proportional to the concentration, and that the peak potential was independent of concentration, allowed us to conclude that this process was irreversible in the temperature range 580 to $800^{\circ} \mathrm{C}$. The

Table III. Kinetic parameters of $\mathrm{TaOF}_{5}^{2-}+5 \mathrm{e}^{-} \rightarrow \mathrm{Ta}+5 \mathrm{~F}^{-}+\mathrm{O}^{2-}$ process (FLINAK- $\mathrm{K}_{2} \mathrm{TaF}_{7}-\mathrm{Na}_{2} \mathrm{O}$ melt, molar ratio

\begin{tabular}{|c|c|c|c|c|}
\hline $\begin{array}{c}T \\
\left({ }^{\circ} \mathrm{C}\right)\end{array}$ & $\begin{array}{c}\text { Peak } \\
\text { current } \\
I_{\mathrm{p}, 1} \\
(\mathrm{~mA})\end{array}$ & $\begin{array}{c}\mathrm{C} \cdot 10^{\overline{8}} \\
\mathrm{~K}_{2} \mathrm{TaF}_{7} \\
\left(\mathrm{~mol} \cdot \mathrm{cm}^{-3}\right)\end{array}$ & $\alpha n_{\alpha}$ & $\underset{\left(\mathrm{cm}^{2} \cdot \mathrm{s}^{-1}\right)}{D \cdot 10^{5}}$ \\
\hline 813 & 25.0 & 1.468 & 2.896 & 3.40 \\
\hline 768 & 23.0 & 1.488 & 2.776 & 2.80 \\
\hline 718 & 20.5 & 1.511 & 2.643 & 2.16 \\
\hline 708 & 19.9 & 1.515 & 2.617 & 2.02 \\
\hline 658 & 17.5 & 1.537 & 2.483 & 1.52 \\
\hline 649 & 17.2 & 1.541 & 2.464 & 1.46 \\
\hline 597 & 5.0 & 1.558 & 2.320 & 1.09 \\
\hline
\end{tabular}
$\mathrm{Na}_{2} \mathrm{O} / \mathrm{K}_{2} \mathrm{TaF}_{7}=1$, scan rate $\left.=0.5 \mathrm{~V} \cdot \mathrm{s}^{-1}, A_{\mathrm{Ag}}=0.31 \mathrm{~cm}^{2}\right)$. 


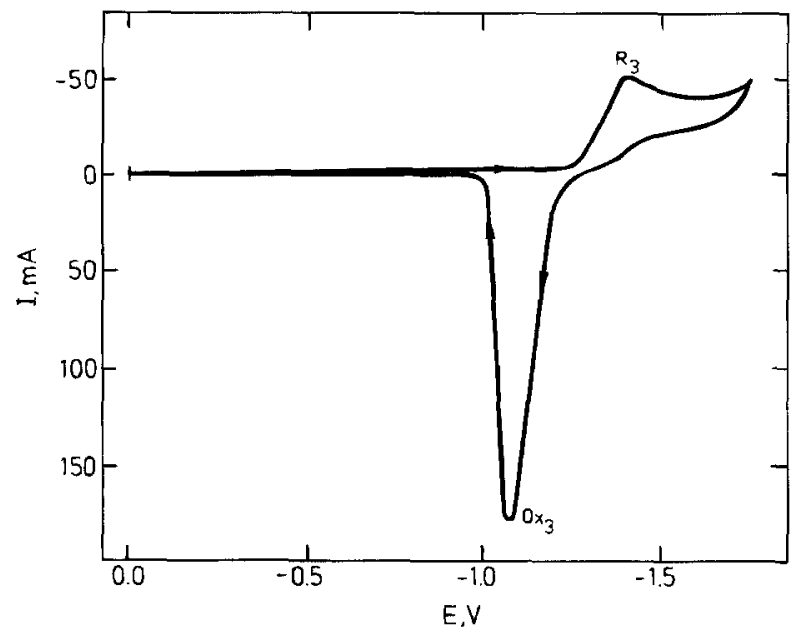

Fig. 12. Cyclic voltammogram of FLINAK-K $\mathrm{TaF}_{7}-\mathrm{Na}_{2} \mathrm{O}$ melts, $T=$ $710^{\circ} \mathrm{C}$, scan rate $0.1 \mathrm{~V} \cdot \mathrm{s}^{-1}, \mathrm{Ag} / \mathrm{AgCl}$ reference electrode. $A_{\mathrm{Ag}}=$ $0.42 \mathrm{~cm}^{2} . \mathrm{C}_{\mathrm{K}_{2} \text { TaF }}=0.406 \mathrm{~m} / \mathrm{o}$. Molar ratio $\mathrm{Na}_{2} \mathrm{O} / \mathrm{K}_{2} \mathrm{TaF}_{7}=2.01$. The oxide content has been corrected with an amount corresponding to $0.029 \mathrm{~m} / \mathrm{o}$ on the basis of the measurements shown in Fig. 6 .

product of the transfer coefficient $(\alpha)$ and the number of electrons $\left(n_{\alpha}\right)$ characterizing the irreversibility of the electrochemical process was calculated using Eq. 9 and its values are given in Table III.

Further, $\alpha n_{\alpha}$ values were calculated from the slope of $E_{\mathrm{p}, 2}$ vs. $\log v$ (Fig. $11 \mathrm{~b}$ ) using Eq. 10. The slope was $K=0.0385$; therefore at $710^{\circ} \mathrm{C}$ the $\alpha n_{\alpha}$ was equal to 2.53 .

Using these $\alpha n_{\alpha}$ values (Table III) the diffusion coefficient for the $\mathrm{Ta}(\mathrm{V})$ monooxofluoro complex was obtained from Eq. 11. The values of the diffusion coefficient for the $\mathrm{Ta}(\mathrm{V})$ monooxofluoro complex calculated from $I_{\mathrm{p}, 2}$ are lower than the real value because of tantalum reduction from dioxofluoro complexes $\left(I_{\mathrm{p}, 3}\right)$ which always occurs to a small extent.

The plot of the logarithm of the $\mathrm{TaOF}_{5}^{2-}$ diffusion coefficient vs. $1 / T$ is a straight line, which can be expressed by the following empirical equation

$$
\log D=-2.35-2293 / T
$$

the activation energy of diffusion determined from its slope being $43.9 \mathrm{~kJ} / \mathrm{mol}$.

The results from linear voltammetry have been confirmed by polarographic data. From these latter measurements it has been found that the limiting current of the reduction wave was directly propotional to the $\mathrm{TaOF}_{5}^{2-}$ concentration, and that the half-peak potentials were not dependent on $\mathrm{Ta}(\mathrm{V})$ concentration.

Analysis of the stationary wave corresponding to the $\mathrm{TaOF}_{5}^{2-}+5 e^{-} \rightarrow \mathrm{Ta}+5 \mathrm{~F}^{-}+\mathrm{O}^{2-}$ reduction process (Fig. $9 \mathrm{~b}$ ) shows that the plot of $\log \left[\left(I_{\ell}-I\right) / I\right]$ vs. $E$ is linear with a slope larger than $2.3 R T / n_{\alpha} F$, indicating an irreversible process. Assuming that Eq. 14 is valid in this case ca,25 $^{21,6}$

$$
E=E_{1 / 2}+\frac{2.303 R T}{\alpha n_{\alpha} F} \log \frac{I_{\ell}-I}{I}
$$

an $\alpha$ value of 0.58 was obtained for $n_{\alpha}$ equal to 5 .

Use of a molar ratio $\left(\mathrm{Na}_{2} \mathrm{O} / \mathrm{K}_{2} \mathrm{TaF}_{7}\right)$ close to two showed the absence of peaks associated with tantalum reduction from $\mathrm{TaF}_{7}^{2-}$ and $\mathrm{TaOF}_{5}^{2-}$ species (Fig. 12). Hence the dioxofluoro complex is formed exclusively and the voltammogram, which exhibits a near cathodic peak and an anodic dissolution peak corresponding to it, is that of the dioxofluoro complex alone. As can be seen from the cyclic voltammogram, the dissolution of the solid product de- posited on the electrode occurs at a marked overvoltage. Electrolysis under potentiostatic conditions with a potential corresponding to this limiting current value gave a reduction product, which XRD data showed to be only $\mathrm{KTaO}_{3}$. Apparently the primary electrochemical step proceeds a chemical reaction involving $\mathrm{KTaO}_{3}$ formation.

\section{Conclusion}

Titration of $\mathrm{TaF}_{7}^{2-}$ ions (dissolved in FLINAK) with oxide ions leads to the stepwise formation of $\mathrm{TaOF}_{5}^{2-}$ and $\mathrm{TaO}_{2} \mathrm{~F}_{x}^{(x-1)-}$ complexes.

Electrochemically $\mathrm{TaF}_{7}^{2-}$ is reduced to tantalum metal in a single quasi-reversible five-electron step. $\mathrm{TaOF}_{5}^{2-}$ is also reduced to metal in a five-electron step but this process is irreversible. Electrochemical reduction of $\mathrm{TaO}_{2} \mathrm{~F}_{x}^{(x-1)}$ - leads to the formation of an insoluble product, $\mathrm{KTaO}_{3}$.

\section{Acknowledgment}

L. P. and E. P. are grateful to the Mads Clausens Foundation for financial support and personally to H. J. Pedersen and to J. Christensen for having made their stay possible at The Technical University of Denmark. I. M. Petrushina and D. H. Kerridge are thanked for valuable discussions.

Manuscript submitted March 16, 1994; revised manuscript received June $30,1994$.

\section{REFERENCES}

1. S. Senderoff, G. W. Mellors, and W. I. Reinhart, This Journal, 112, 840 (1965).

2. D. Inman, R. P. Sethi, and R. Spencer, J. Electroanal. Chem., 29, 137 (1971).

3. P. Taxil and J. Mahenc, Corros. Sci., 21, 31 (1981).

4. P. Taxil, J. Less-Common Met., 113, 89 (1985).

5. P. Taxil and J. Mahenc, J. Appl. Electrochem., 17, 261 (1987).

6. K. H. Stern and D. R. Rolison, This Journal, 136, 3760 (1989).

7. A. Espinola, A. J. B. Dutra, and F. T. Silva, Anal. Chim. Acta, 251, 53 (1991).

8. V. I. Konstantinov, E. G. Polyakov, and P. T. Stangrit, Electrochim. Acta, 23, 713 (1978).

9. J. S. Fordyce and R. L. Baum, J. Phys. Chem., 69, 4335 (1965).

10. J. S. Fordyce and R. L. Baum, J. Chem. Phys., 44, 1166 (1966).

11. J. H. von Barner, R. W. Berg, N. J. Bjerrum, E. Christensen, and F. Rasmussen, Mater. Sci. Forum, 73-75, 279 (1991).

12. J. Hinden, J. Augustynski, and R. Monnier, Electrochim. Acta, 21, 459 (1976).

13. E. Christensen, X. Wang, J. H. von Barner, T. Østvold, and N. J. Bjerrum, This Journal, 141, 1212 (1994).

14. A. J. Calandra, C. E. Castellano, and C. M. Ferro, Electrochim. Acta, 24, 425 (1979).

15. L. P. Polyakova, E. G. Polyakov, A. I. Sorokin, and P. T. Stangrit, J. Appl. Electrochem., 22, 628 (1992).

16. R. P. Elliot, Constitution of Binary Alloys, 1st Suppl., M. Metallurgia, Vol. 2 (1970).

17. M. Hansen and K. Anderko, Constitution of Binary Alloys, McGraw-Hill, New York (1958).

18. S. H. White, in Molten Salt Techniques, D. Lovering and R. Gale, Editors, Vol. 1, p. L, Plenum Press, New York (1983).

19. J. P. Chaminade, V. Vlasse, M. Pouchard, and P. Hagenmuller, Bull. Soc. Chim. Fr. 9/10, 1791 (1974).

20. J. P. Chaminade, M. Pouchard, and P. Hagenmuller, Rev. Chim. Miner, 9, 381 (1972).

21. Z. Galus, Fundamentals of Electrochemical Analysis, Ellis Harwood Ltd., Chichester (1976).

22. F. Lantelme, A. Barhoun, and G. Li, This Journal, 139, 1249 (1992).

23. H. Matsuda and Y. Ayabe, Z. Electrochem., 59, 494 (1955).

24. P. Delahay, New Instrumental Methods in Electrochemistry, Interscience, New York (1954).

25. J. Heyrovsky and J. Kuta, Principles of Polarography, Academic Press, New York (1966). 